\title{
ENVENOMING BY CORAL SNAKES (Micrurus) IN ARGENTINA DURING THE PERIOD BETWEEN 1979-2003
}

\author{
Adolfo Rafael de ROODT(1,2), Ernesto DE TITTO(3), Jorge Adrián DOLAB(4) \& Jean-Philippe CHIPPAUX(5,6)
}

\begin{abstract}
SUMMARY
Envenomation by coral snakes (Micrurus sp.) is one of the most dangerous injuries in America and it is considered as a serious medical emergency, however bites by these snakes appear to be rare. We analyzed epidemiological data, clinical signs and antivenom use in Argentina during the period between 1979-2003. During this period of study 46 non-fatal Micrurus bites were reported. The majority of cases were men from 31 to 40 years old. Bites occurred primarily in spring and summer. Most cases were reported from the northeast and northwest provinces of the country. The bites were mostly located on hands or feet and occurred mostly during agricultural activities and so mainly involved farmers. Only four cases occurred as a result of handling snakes. The median time it took for antivenom to be administrated was 60 minutes after the bite, and the median number of vials applied was 2 . Local pain was mentioned and edema was reported in $41 \%$ of patients. All patients recovered without sequelae. This study showed a low incidence of Micrurus bites and low severity of envenomation. However, although no deaths have been reported during the last 30 years, given the toxicity of the venom of Micrurus snakes, the risk of severe envenomation should be considered.
\end{abstract}

KEYWORDS: Snakes; Envenoming; Micrurus; Epidemiology; Snakebite; Antivenom.

\section{INTRODUCTION}

Coral snakes are endemic in the Americas from the South of United States of America to the South of Argentina, in the Patagonian region. They represent a potential risk to human health throughout the continent.

Coral snakes belong to the Elapidae family which constitutes a taxonomic group of over 120 species and subspecies ${ }^{7}$, represented by the genera Micrurus, Micruroides and Leptomicrurus. Micrurus is the main genus, containing more than 70 species $^{7}$, six of which can be observed in Argentina. The species described are Micrurus (M.) altirostris, $M$. balyocoriphus, M. corallinus, $M$. frontalis, M. lemniscatus and $M$. pyrrhocryptus ${ }^{24}$.

Micrurus bites are less frequent than snakebites from Crotalinae in the Americas $5,10,14,23,24,25,33,42$. In Central America and Colombia less than $2 \%$ of all snakebites have been related to bites by Micrurus spp. ${ }^{5,8}$, while in Brazil coral snakes accounted for $0.65 \%$ (486 out of 75,312) of bites by venomous snakes in the period between 2001-2004, with no recorded deaths ${ }^{6}$. In the United States of America, bites by coral snakes (principally by $M$. fulvius) represent $3.6 \%$ of accidents involving indigenous venomous snakes, based on records from the last 20 years (911 coral snake bites from a total of 25,551 bites by venomous snakes in the period between 1983-2003) ${ }^{1}$, which equates to around 45 bites/ year; while another report accounts for 1254 bites by Micrurus in the period between $1983-2007^{41}$, leading to $50 \pm 31$ bites per year, this is in the same range as previous report.

Deaths occuring from Micrurus bites are uncommon. The fact that coral snake bites are rare is evidence of their reclusive nature, lack of aggressiveness, shyness and the low effectiveness of their venom delivery apparatus when compared to that of pit vipers ${ }^{29}$.

Micrurus bites produce a neurotoxic envenoming, which can lead to peripheral paralysis of respiratory muscles in animals and humans ${ }^{6,21,34}$. The neurological symptoms may involve 1) a block of the postsynaptic cholinergic receptor by toxic peptides called $\alpha$-neurotoxins, e.g. $M$. frontalis frontalis; 2 ) the inhibition of acetylcholine release related to presynaptic phospholipases $\mathrm{A}_{2}\left(\mathrm{PLA}_{2}\right.$ ) (called $\beta$-neurotoxins), in addition to postsynaptic blocking, e.g. M. corallinus; and/or 3) a combined action of $\alpha$-neurotoxins and myotoxic PLA 2 , e.g. M. nigrocinctus and M. fulvius ${ }^{39,40}$.

In some experiments cardiovascular ${ }^{15}$ and hemorrhagic activities were observed in a few coral snake venoms such as those of $M$. fulvius ${ }^{37}$, M. averyi ${ }^{3}$ and $M$. frontalis frontalis ${ }^{17}$. There are no reports of clotting

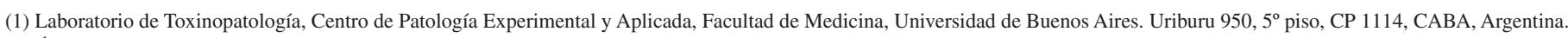

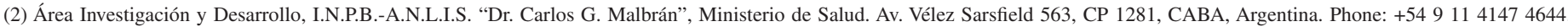
E-mail: aderoodt@gmail.com

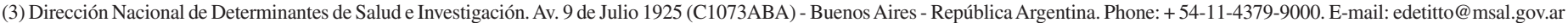

(4) Departamento Vacunas y Sueros, I.N.P.B.-A.N.L.I.S. "Dr. Carlos G. Malbrán", Ministerio de Salud.

(5) Institut de Recherche pour le Développement.

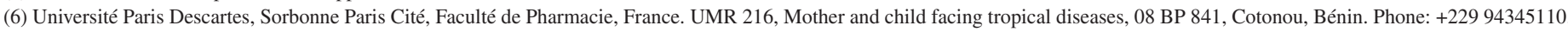
E-mail: jean-philippe.chippaux@ird.fr

Correspondence to: Adolfo Rafael de Roodt. E-mail: aderoodt@ gmail.com 
de ROODT, A.R.; DE TITTO, E.; DOLAB, J.A. \& CHIPPAUX, J.-P. - Envenoming by coral snakes (Micrurus) in Argentina, during the period between 1979-2003. Rev. Inst. Med. Trop. Sao Paulo, 55(1): 13-8, 2013.

activity with plasma or fibrinogen in the venoms of South American coral snakes ${ }^{17}$. However, some South American Micrurus showed edema which induced inflammatory activity ${ }^{3}$ and increased capillary permeability ${ }^{36}$. Although local lesions are uncommon, some Micrurus venoms have shown experimental myotoxic effects in mice ${ }^{2,3,18}$.

While there are detailed clinical reports and summaries regarding envenoming by coral snakes (M. fulvius) in North America ${ }^{1,21,23,30,31}$, such information does not exist in South America, although some case reports have been published in the last few decades ${ }^{6,22,31}$. Despite the important material regarding envenomings by Micrurus in South and Central America and the characteristics of their venoms and antivenoms, we are still lacking detailed descriptions of clinical or epidemiological characteristics of coral snake envenoming.

This is an account of data collected from epidemiological reports submitted to national health authorities, regarding patients bitten by coral snakes during the last 25 years in Argentina.

\section{METHODS}

This study is a retrospective analysis of available information from the former national program for snakebites $(\mathrm{PNO}=$ Programa Nacional de Ofidismo) from January 1979 to December 2003. All patients that were described as having been exposed to a coral snake bite were included.

Information was recorded in regular data sheets used by the PNO to report the use of antivenoms. Data took into account patient age, sex, location where the accident occurred, date and circumstance of the accident (inside or outside home, at work, etc.), anatomical site of the Micrurus bite, and signs and/or symptoms recorded at the time of medical examination. It also recorded the time elapsed between the bite and the treatment, the amount of antivenom given to the patient, and the clinical evolution of the case.

Specific incidences were calculated according to the provincial population of Argentinean provinces and the demographic distribution of ages in $1991^{20}$. The $\chi^{2}$ test was used to compare the results where necessary.

\section{RESULTS}

A total of 46 coral snake bites have been reported during the 25 year period, i.e. an average of two bites per year. In 1995, eight bites were observed, the highest number of bites in a single year (Fig. 1). The seasonal distribution of Micrurus bites, showed the highest incidence from mid-spring (October) to autumn (April) (Fig. 2). As regards the geographical distribution, most of bites occurred in the Northwest Province while only one case was reported from Patagonia (Fig. 3). No deaths were recorded.

The age group most affected by snakebites was that of 31-40 years (34\%), with males being most affected by snakebites (70\%) (Fig. 4). The majority of bites occurred during working activities (44\%) and in rural areas (55\%). Only four illegitimate bites were related to snake handling.

Hands and feet were the most frequent anatomical site of the bites, accounting for $82 \%$ of all bites; with hands and forearms $45.6 \%$, and

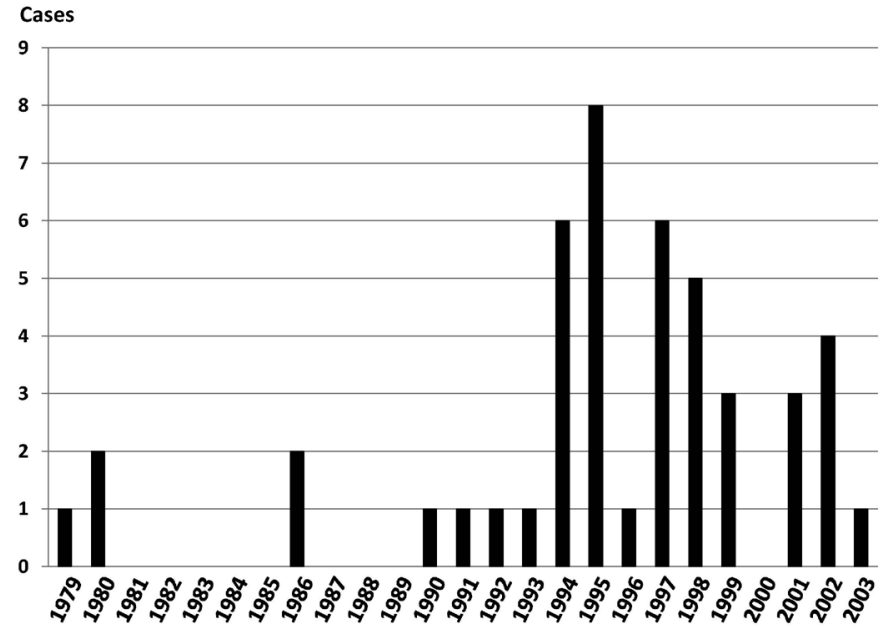

Fig. 1 - Annual occurrence of cases between 1979-2003.

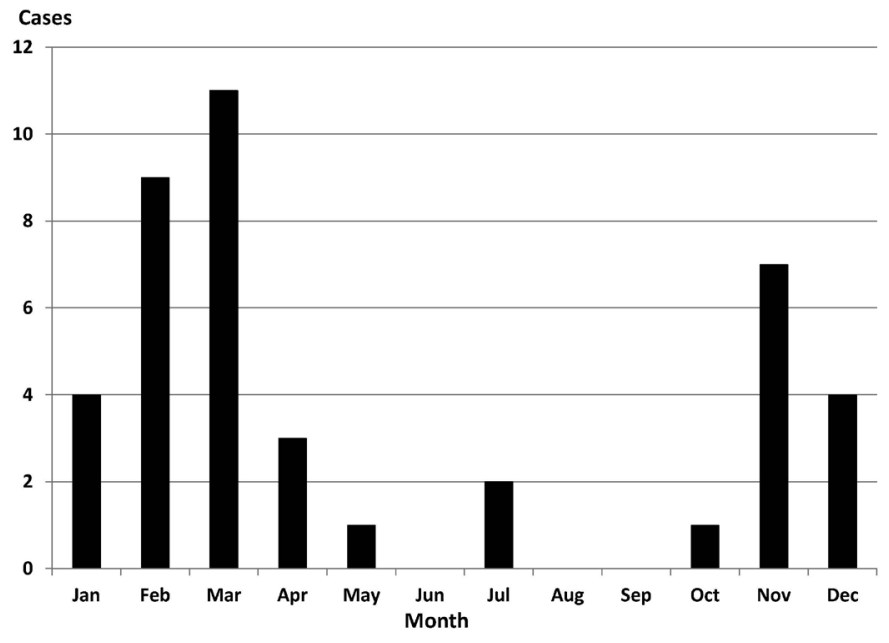

Fig. 2 - Seasonal occurrence of Micrurus bites in Argentina.

feet and ankles 54.4\%.

Interestingly, most patients presented local symptoms. Pain was present in 31 patients $(68.9 \%)$ and edema was reported in 15 patients $(33.3 \%)$. Other manifestations were rare: two patients reported burning $(4.4 \%)$, while myalgia and arthralgia were reported in three $(6.7 \%)$ and two $(4.4 \%)$ cases respectively.

Systemic signs were described in few cases: dizziness, tachycardia, hypertension and sickness (one case each, 2.2\%); paleness (two cases, $4.4 \%$ ), tremors (four cases, $8.8 \%$ ), while dispnoea and/or respiratory difficulty were reported in four cases $(8.8 \%)$.

All patients received antivenom, which was a mandatory part of filling in the PNO report form. However, in nine cases the antivenom administered was not the specific one. In the 36 cases in which the specific antivenom was used, the median of injected vials was two (minimum one, maximum eight). The mean time for antivenom to be administrated after the bite was $194 \mathrm{~min}$ (from $15 \mathrm{~min}$ to 48 hours), while the median time between the bite and the treatment was 60 minutes. 

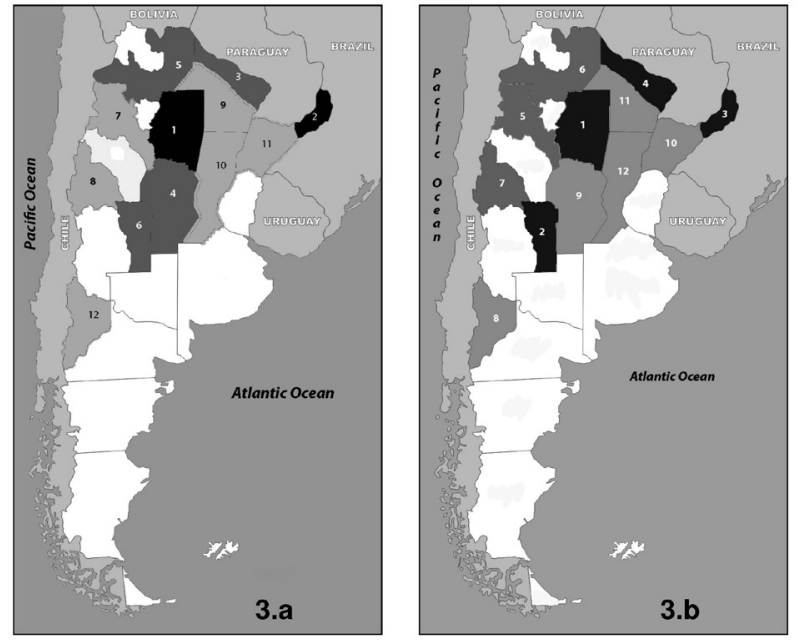

Fig. 3 - Geographical specific incidence according to Argentinean Provinces. 3.a. Number of cases of accidents by Micrurus in each province. 1 - Santiago del Estero (11 cases), 2 Misiones (10 cases), 3 - Formosa (five cases), 4 - Córdoba (five cases), 5 - Salta (four cases), 6 - San Luis (four cases), 7 - Catmarca (two cases), 8 - San Juan (two cases), 9 - Chaco, 10 - Santa Fe, 11 - Corrientes, 12 - Neuquén (one case in each province). 3.b. Specific Incidence by province (cases/100,000 inhabitants). 1 - Santiago del Estero (1.63691), 2 - San Luis (1.39860), 3 - Misiones (1.26743), 4 - Formosa (1.25628), 5 - Catamarca (0.75758), 6 - Salta (0.46189), 7 - San Juan (0.37807), 8 - Neuquén (0.25707), 9 - Córdoba (0.18070), 10 - Corrientes (0.12563), 11 - Chaco (0.11905), 12 - Santa Fe (0.03579).

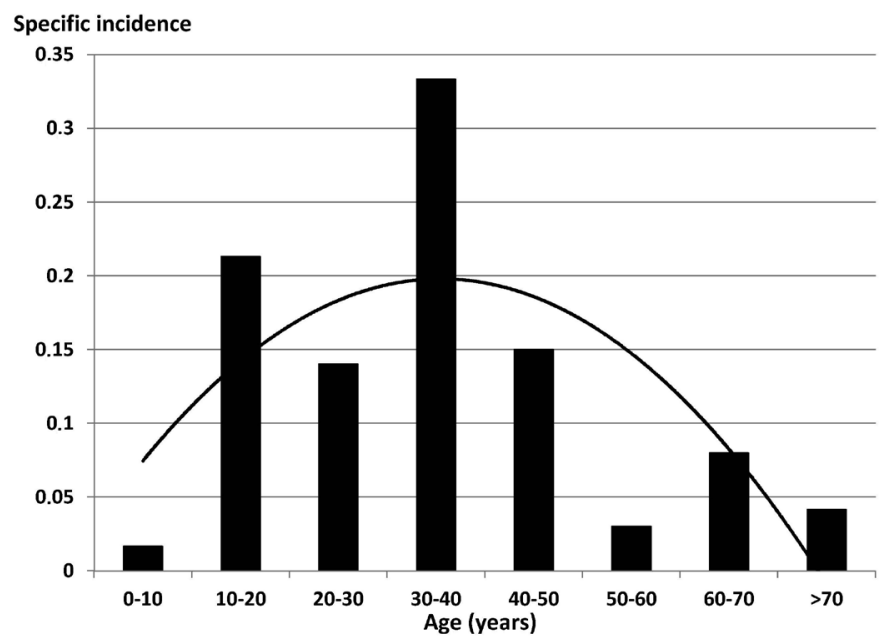

Fig. 4 - Specific incidence according to age distribution in the Argentinean population (the trend curve was based on a polynomial model).

In all cases the antivenom used for treatment was the Antiveneno Micrurus from the National Institute for Production of Biologicals of the National Administration of Laboratories and Institutes of Health, "Dr. Carlos G. Malbrán", depending of the National Ministry of Health. This was (and is) the only available antivenom for treatment of coral snakes in Argentina. The pharmaceutical is in liquid form, in $5 \mathrm{~mL}$ vials containing $\mathrm{F}(\mathrm{ab})_{2}$, fragments of equine immunoglobulins. The neutralization is $1 \mathrm{mg}$ or more of venom by $\mathrm{mL}$ of antivenom (which means at least $5 \mathrm{mg}$ of venom neutralized per vial). The information on the antivenom used was included in the PNO sheets.
In some cases, antivenom was used in association with additional drugs: corticoids (32 cases, $71.1 \%$ ), corticoids plus antihistamines (six cases, $13.3 \%$ ), antitetanic toxoid (14 patients, 31.1\%), antibiotics (seven patients, $15.6 \%$ ) and analgesics in five cases $(11.1 \%)$.

The duration of hospitalization ranged from one to four days. The outcome was good in all cases, without any sequels reported.

\section{DISCUSSION}

All Micrurus bites reported to the PNO in Argentina during the years 1979 to 2003 were analyzed except two of them that had been recorded twice. Since 2004, case reporting to PNO has been irregular and so it was not possible to continue the analysis.

The scarcity of cases reported before 1990, could be explained by an irregular distribution of antivenoms and/or, by a more parsimonious management of snakebites, but any possible reasons are difficult to determine retrospectively. Considering that the annual incidence of snakebites in Argentina is about 1,000 bites a year ${ }^{12}$, the frequency of coral snake bites was very low, representing only $0.2 \%$ of total snakebites.

The geographical distribution was irregular and decreased from north to south, this variation was possibly due to the abundance of Micrurus, the human population density or, perhaps, human activities. The highest frequency of bites was recorded in four Northern provinces (Salta, Santiago del Estero, Formosa and Misiones), where 65\% of accidents occurred. The risk gradually decreased going south to northern Patagonia, where only a single bite by Micrurus was reported in 25 years.

Taking into consideration the provinces where the accidents occurred, $M$. pyrrhocryptus was responsible for more than a half of the bites. However, no difference was observed in a clinical presentation of bites when $M$. pyrrhocryptus was involved compared to other species, even in the Misiones province where six different species of Micrurus are encountered $\left(\chi^{2}=0.8887 ; p=0.62\right)$.

Micrurus are not aggressive and often shy. Contrary to an erroneous reputation about Micrurus which states that they cannot bite because their mouth is too small and opens only slightly, coral snakes are able to bite and inoculate their venom. However, the amount of venom obtained from these snakes is low ${ }^{9,15,16,19,34}$. The yield of venom from Argentinean Micrurus is about $14 \pm 6 \mathrm{mg}$ per adult snake ${ }^{11}$ ranging from $1 \mathrm{mg}$ in small specimens to more than $40 \mathrm{mg}$ in very large snakes (de ROODT unpublished results), as is the case for most South American Micrurus. In addition, the very short and fixed fangs and the absence of a closed duct to inject the venom, reduce the effectiveness of venom inoculation in comparison to vipers. As a consequence, not all bites result in envenoming. Significant clinical symptoms are recorded in approximately $40 \%$ of Micrurus bites reflecting venom inoculation ${ }^{30,32,33}$, which seems to be slightly lower than elapid envenomings reported from other continents where the incidence of clinical disorders is estimated at $50-60 \%$ in humans ${ }^{7,9}$. However, it is well known that even a venomous snake may inflict a dry bite ${ }^{6,35}$. It is also possible that the rapid management of patients, half of which are treated within one hour after the bite, could explain the absence of death and severe envenoming among patients of Argentina. Most of them did not show any systemic disorder. Only four patients presented respiratory symptoms that quickly disappeared after 
de ROODT, A.R.; DE TITTO, E.; DOLAB, J.A. \& CHIPPAUX, J.-P. - Envenoming by coral snakes (Micrurus) in Argentina, during the period between 1979-2003. Rev. Inst. Med. Trop. Sao Paulo, 55(1): 13-8, 2013.

antivenom administration. In contrast, $70 \%$ of them showed local signs, which is consistent with observations published elsewhere ${ }^{28}$.

In this study, no deaths were observed. However, nearly $10 \%$ of patients had respiratory symptoms that could have lead to severe complications. The venom of the Argentinean Micrurus is as toxic as the venom of Micrurus that causes death in other countries ${ }^{13,19,26,34,38}$. In Brazil, a country with very similar characteristics regarding the fauna and snakebite epidemiology, Micrurus bites are also uncommon ${ }^{4,14,25,27,31}$ and usually mild ${ }^{6,9}$ representing about $0.4 \%$ of total snakebites with $0.36 \%$ mortality ${ }^{25}$, which is very consistent with our results.

During the period of study the treatment with antivenom was highly variable, ranging between 1-8 vials. However, recent official recommendations from the national authorities suggest the application of 10 vials $^{24}$, as recommended by the Ministry of Health of Brazil ${ }^{25}$. No clinical trial has been conducted in Argentina so far and so until this is possible the recommended doses are those suggested in Brazil, because of their experience of such accidents. Although the population of Micrurus snakes is not identical, all the Micrurus species that inhabit Argentina can be found in the South of Brazil 1,9,24,25. The number of vials recommended is the same, nevertheless, the neutralizing potency of Argentinean antivenom by vial could be lower than the Brazilian one, since the neutralization capacity of Argentinean antivenom during the period of study was of 5-10 mg per $5 \mathrm{~mL}$ vial (DOLAB J.A., unpublished data) versus $15 \mathrm{mg}$ per $10 \mathrm{~mL}$ vial (at least $1.5 \mathrm{mg} / \mathrm{mL}$ ) of the Soro Antielapídico produced by the Butantan Institute (Sao Paulo, Brazil). However, it is difficult to compare the potencies because of the different methods used for determining the neutralization of these antivenoms in both countries (i.e. type and characteristic of the venoms used for determination, challenge doses of venom, inoculation route of the experimental animals used for the assay, among others). Clinical trials are necessary in order to establish the optimal dose of the antivenom in Argentina.

Our data were collected through the "Programa Nacional de Ofidismo". This program relied upon cases being reported by health care professionals. As a routine passive surveillance system, an underregistration of snake bite reports can be expected for many reasons. Among the potential reasons are: a lack of antivenom that leads to people doubting the usefulness of the surveillance system, a lack of health professionals for operational issues, or patients being unable to access a health center for antivenom therapy.

Although this type of system has several weaknesses, because all cases of Micrurus bites hold potential for severe envenoming in this country, these accidents are always reported and given precedence over the lack of antidote, the provincial and national sanitary authorities are required to treat the case. Therefore the antivenom (there is only one producer in the country) is sent via sites of the Ministry of Health and after treatment, the surveillance sheets are completed and sent.

One issue that is impossible to solve is when patients do not access the health center for the antivenom treatment. This is possibly the key weakness in this notification system.

Another problem regarding the notification system, based on patient reports, is a possible over registration of cases where it is only a suspected Micrurus bite and not a confirmed diagnosis. We discarded all cases where there was evidently some doubt concerning the clinical data or where another type of snakebite was indicated. Nevertheless, false coral snake bites may be a cause of misdiagnosis. In Argentina there are several species of false coral snakes, such as the species of Lystrophis, Oxyrrhopus and Erythrolampus. The lack of experience and familiarity of health professionals regarding red, white and black color pattern combinations placed in rings, could cause a misdiagnosis or mistaking a colubrid snake as a coral "dry bite". Although this is certainly a possibility, professionals in health centers where snakebites are common receive instructions regarding the identification of true coral snake or false coral snake, which would theoretically diminish diagnostical errors. However, although bites misdiagnosed as false coral snake bites could be present among the cases considered in our study, the regions and centers where cases occurred and cases were attended indicate to us a high likelihood that the diagnosis of coral snake bites can be relied upon.

Despite the aforementioned, the key symptoms described in coral snake envenoming are due to the main venom action, which is neurotoxicity. However, symptoms such as myasthenia, palpebral ptosis, diplopia, or blurred vision were not described in data sheets recorded. This could be attributed to the physicians attending the emergency room not completely filling the spaces for recording specific clinical symptoms (due to work overload) and only noting down the most obvious symptoms. Finally, the other possibility is that there was only a very slight envenomation by coral snake bite due to a low injection of venom in the cases reported.

We are currently using new systems of collecting data on accidents involving venomous animals, and modified epidemiological sheets. It is possible that these changes along with the improvement of communication systems from the peripheral centers (where the snakebites occur) and the central levels (which collect and analyze data), will improve our knowledge regarding the envenomation by venomous animals in general and by coral snakes in particular.

In Argentina, Micrurus bites are rare and cause very few severe envenomings. This may be due to a small amount of venom injected, or the small size of the animal, or because the venom apparatus and the limited ability of the venom glands do not allow an effective inoculation of venom. However, although no deaths have been recorded over the past 30 years, the toxicity of the venom is high and the risk of severe envenoming should be considered. The specific antivenom is available throughout the country and should be administered early in all patients suffering from envenoming after Micrurus bites.

\section{RESUMO}

\section{Envenenamento por cobras corais na Argentina durante o período 1979-2003}

O envenenamento por corais (Micrurus sp.) é um dos mais perigosos na América e considerado uma emergência médica grave ainda que acidentes por estas serpentes pareçam raros. Analisamos dados epidemiológicos e clínicos e o uso de soro antiofídico, durante o período de 1979-2003. As comunicações indicam 46 acidentes por Micrurus, aproximadamente dois casos anuais, sem registro. A maioria 
dos casos ocorreu em homens de idade entre 31 e 40 anos, principalmente no período de primavera e verão e provenientes do noroeste e nordeste do país. Os acidentes na sua maioria ocorreram em mãos e pés, durante atividades agrícolas envolvendo trabalhadores rurais. Apenas quatro acidentes foram relacionados a manejo dos animais. Em todos os casos analisados houve descrição de dor local e em $41 \%$ dos pacientes houve edema. Por paciente foram administradas, em média, duas ampolas. $\mathrm{O}$ tempo médio de aplicação do soro foi de 60 minutos. Em todos os casos a recuperação foi favorável sem presença de sequelas. Neste estudo foi possível observar uma baixa incidência de acidentes e baixa severidade nos envenenamentos. Apesar de que não aconteceram mortes nos últimos 30 anos, dado a toxicidade do veneno das cobras corais, o risco de envenenamento severo deveria ser considerado.

\section{ACKNOWLEDGEMENTS}

The authors would like to dedicate this manuscript in memorian of Engineer Raul Funes, who recorded the data regarding envenomation by venomous animals received in the National Institute for Production of Biologicals of the Ministry of Health, Argentina.

Authors are gratefull to DVM/BSc Vanessa Costa de Oliveira by her helpful advice in writing the Resumo in Portuguese.

Authors are also grateful to the blind Reviewers for their suggestion and corrections that improve the quality of the manuscript.

\section{REFERENCES}

1. The American Association of Poison Control Centers (AAPCC-TESS). Toxic Exposure Surveillance System) Annual Reports 2005. Available from: http://www.aapcc.org/ $\mathrm{dnn} /$ Portals/0/2005\%20Published\%20Annual\%20Report.pdf

2. Arroyo O, Rosso JP, Vargas O, Gutiérrez JM, Cerdas L. Skeletal muscle necrosis induced by a phospholipase A2 isolated from the venom of the coral snake Micrurus nigrocinctus nigrocinctus. Comp Biochem Physiol B. 1987;87:949-52.

3. Barros AC, Fernández DP, Ferreira LCL, Dos Santos MC. Local effects induced by venoms from five species of genus Micrurus sp. (coral snakes). Toxicon. 1994;32:445-52.

4. Bochner R, Struchiner CJ. Aspectos ambientais e sócio-econômicos relacionados à incidência de acidentes ofídicos no Estado do Rio de Janeiro de 1990 a 1996: uma análise exploratória. Cad Saúde Pública. 2004;20:976-85.

5. Bolaños R. Las serpientes venenosas de Centroamérica y el problema del ofidismo. Primera parte. Aspectos zoológicos, epidemiológicos y biomédicos. Rev Costarric Cienc Méd. 1982;3:165-85.

6. Bucaretchi F, Hyslop S, Vieira RJ, Toledo AS, Madureira PR, De Capitani EM. Bites by coral snakes (Micrurus spp.) in Campinas, State of São Paulo, Southeastern Brazil. Rev Inst Med Trop Sao Paulo. 2006;48:141-5.

7. Campbell JA, Lamar WW. The venomous reptiles of the Western Hemisphere. Ithaca Comstock Publishing Associates; 2004. v.1, p.188-233.

8. Charry-Restrepeoe H. Accidentes por serpientes de coral (Micrurus sp.). In: Memorias del Primer Simposio de Toxinología Clínica "César Gómez Villegas". Bogotá: Laboratorios Probiol Ltda/Facultad de Medicina Fundación Universitaria San Martín; 2006.

9. Da Silva Jr NJ, Bucaretchi F. Mecanismo de ação do veneno elapídico e aspectos clínicos dos acidentes. In: Cardoso JL, França FO, Wen FW, Málaque CMS, Haddad Jr V., editores. Animais peçonhentos no Brasil. Biologia, clínica e terapêutica dos acidentes. São Paulo: Sarvier \& FAPESP; 2003. p. 99-107.
10. de Roodt AR. Estudio inmunobiológico del veneno de las serpientes de importancia sanitaria de la Argentina. [PhD Thesis]. Buenos Aires: Facultad de Farmacia y Bioquímica de la Universidad de Buenos Aires; 2002. p. 11-21.

11. de Roodt AR, Dolab JA, Galarce PP, Gould E, Litwin S, Dokmetjian C, et al. A study on the venom yield of snake species from Argentina. Toxicon. 1998;36:1949-57.

12. de Roodt AR, Oliveira V, de Pietri D, García SI. Accidentes por animales venenosos comunicados al Ministerio de Salud de la Nación en el período 2005-2009. Acta Toxicol Argent. 2010;18(Suppl.):63

13. de Roodt AR, Paniagua-Solis JF, Dolab JA, Estévez-Ramírez J, Ramos-Cerrillo B, Litwin $\mathrm{S}$, et al. Effectiveness of two common antivenoms for North, Central and South American Micrurus envenomations. J Toxicol Clin Toxicol. 2004;42:171-8.

14. Fan HW, Cardoso JLC. Clinical toxicology of snake bites in South America. In: Meier J, White J, editors. Handbook of clinical toxicology of animal venoms and poisons. Boca Raton: CRC Press; 1995. p. 667-8.

15. Fix JD. Venom yield of the North American coral snake and its clinical significance. South Med J. 1980;73:737-8.

16. Fix JD, Minton SA Jr. Venom extraction and yields from the North American coral snake, Micrurus fulvius. Toxicon. 1976;14:143-5.

17. Francis BR, da Silva Júnior NJ, Seebart C, Casais e Silva LL, Schmidt JJ, Kaiser II. Toxins isolated from the venom of the Brazilian coral snake (Micrurus frontalis frontalis) include hemorrhagic type phospholipases A2 and postsynaptic neurotoxins. Toxicon. 1997;35:1193-203.

18. Gutiérrez JM, Rojas G, Da Silva Júnior NJ, Nuñez J. Experimental myonecrosis induced by the venoms of South American Micrurus (coral snakes). Toxicon. 1992;30:1299-302.

19. Higashi HG, Guidolin R, Caricati CP, Fernandes I, Marcelino JR, Morais JF, et al Antigenic cross-reactivity among components of Brazilian Elapidae snake venoms. Braz J Med Biol Res. 1995;28:767-71

20. Instituto Nacional de Estadística y Censos. INDEC. [Cited: 2011, June 28]. Available from: http://www.indec.gov.ar/

21. Kitchens CS, Van Mierop LH. Envenomation by the Eastern coral snake (Micrurus fulvius fulvius). A study of 39 victims. JAMA. 1987;258:1615-8.

22. Manock SR, Suarez G, Graham D, Avila-Aguero ML, Warrell DA. Neurotoxic envenoming by South American coral snake (Micrurus lemniscatus helleri): case report from eastern Ecuador and review. Trans R Soc Trop Med Hyg. 2008;102:1127-32.

23. McCullough NC, Gennaro JF. Coral snake bites in the United States. J Florida Med Assoc. $1963 ; 49: 968-72$

24. Ministerio de Salud. Argentina. Guía de Prevención, Diagnóstico, Tratamiento y Vigilancia Epidemiológica de los envenenamientos ofídicos. Buenos Aires: Ministerio de Salud; 2007. $48 \mathrm{p}$.

25. Ministério da Saúde. Brasil. Fundação Nacional de Saúde. Manual de diagnóstico e tratamento de acidentes por animais peçonhentos. Brasília: Ministério da Saúde/ Fundação Nacional da Saúde; 1999. 131 p.

26. Moraes FV, Souza-e-Silva MC, Barbaro KC, Leitão MA, Furtado MF. Biological and immunochemical characterization of Micrurus altirostris venom and serum neutralization of its toxic activities. Toxicon. 2003;41:71-9.

27. Nascimento SP. Aspectos epidemiológicos dos acidentes ofídicos ocorridos no Estado de Roraima, Brasil, entre 1992 e 1998. Cad Saúde Pública. 2000;16:271-6.

28. Nishioka SA, Silveira PV, Menzes LB. Coral snake bite and severe local pain. Ann Trop Med Parasit. 1993;87:429-31.

29. Norris RL, Dart RC. Apparent coral snake envenomation in a patient without visible fang marks. Am J Emerg Med. 1989;7:402-5. 
30. Norris RL, Pfalzgraf RR, Laing G. Death following coral snake bite in the United States: first documented case (with ELISA confirmation of envenomation) in over 40 years Toxicon. 2009;53:693-7.

31. Pardal PP, Pardal JS, Gadelha MA, Rodrigues LS, Feitosa DT, Prudente AL, et al. Envenomation by Micrurus coral snakes in the Brazilian Amazon region: report of two cases. Rev Inst Med Trop Sao Paulo. 2010;52:333-7.

32. Parrish HM, Khan MS. Bites by coral snakes: report of 11 representative cases. Am J Med Sci. 1967;253:561-8.

33. Russell FE, Walter FG, Bey TA, Fernandez MC. Snakes and snakebite in Central America. Toxicon. 1997;35:1469-522.

34. Sanchez EF, Freitas TV, Ferreira-Alves DL, Velarde DT, Diniz MR, Cordeiro MN, et al. Biological activities of venoms from South American snakes. Toxicon. 1992;30:95103

35. Silveira PV, Nishioka SA. Venomous snake bite without clinical envenoming ('dry-bite'). A neglected problem in Brazil. Trop Geogr Med. 1995;47:82-5.

36. Tambourgi DV, dos Santos MC, Furtado MF, de Freitas MC, da Silva WD, Kipnis TL. Pro-inflammatory activities in elapid snake venoms. Br J Pharmacol. 1994;112:723-7.
37. Tan NH, Ponnudurai G. The biological properties of venoms of some American coral snakes (Genus Micrurus). Comp Biochem Physiol B. 1992;101:471-4

38. Tanaka GD, Furtado MF, Portaro FCV, Sant'Anna OA, Tambourgi DV. Diversity of Micrurus snake species related to their venom toxic effects and the prospective of antivenom neutralization. PLOS Negl Trop Dis. 2010;4:e622.

39. Vital Brazil O. Pharmacology of coral snake venoms. Mem Inst Butantan. 1990;52:31-2.

40. Vital Brazil O. Coral snake venoms: mode of action and pathophysiology of experimental envenomation. Rev Inst Med Trop Sao Paulo. 1987;29:119-26.

41. Walter FG, Stollz U, Shirazi F, McNally J. Temporal analyses of coral snakebite severity published in the American Association of Poison Control Centers' Annual Reports from 1983 through 2007. Clin Toxicol (Phila). 2010;48:72-8.

42. Weis R, McIsaac RJ. Cardiovascular and muscular effects of venom from coral snake, Micrurus fulvius. Toxicon. 1971;9:219-28.

Received: 4 January 2012

Accepted: 6 August 2012 